\title{
Pengaruh Disiplin, Konflik Kerja Dan Stres Kerja Terhadap Kinerja Karyawan Pada PT. Sukses Usaha Nirwana
}

\author{
${ }^{1}$ Ina Namora; ${ }^{2}$ Windy; ${ }^{3}$ Sharon; ${ }^{4}$ Stephani \\ Fakultas Ekonomi, Universitas Prima Indonesia \\ E-mail : stephanili35@gmail.com
}

\begin{abstract}
Employees who are less motivated at work can also cause work stress that has an impact on the employee's performance. This study uses a saturated sampling technique. A total population of 63 people and 30 people were taken from the Medan Center Point Fishermen's Office for validity testing. Theories used to support research are theories of human resource management related to discipline, work conflict and work stress and performance. The research method used is a quantitative approach to the type of quantitative descriptive research. Methods of data collection by interview, distribution of questionnaires and study of documentation. The analytical method used is multiple linear regression. The results showed that discipline, work conflict and work stress simultaneously and partially had a significant positive effect on employee performance with a coefficient of determination.
\end{abstract}

Keyword : Discipline; Work Conflict; Work Stress; Employee Performance

\begin{abstract}
ABSTRAK
Karyawan yang kurang mendapat motivasi dalam bekerja itu juga dapat menyebabkan stress kerja yang berdampak pada kinerja karyawan tersebut. Penelitian ini menggunakan teknik sampling jenuh. Jumlah populasi sebanyak 63 orang dan 30 orang diambil dari Kantor Restoran Nelayan Center Point Medan untuk uji validitas. Teori di gunakan untuk mendukung penelitian adalah teoriteori manajemen sumber daya manusia yang berkaitan disiplin, konflik kerja dan stress kerja dan kinerja. Metode penelitian yang digunakan adalah pendekatan kuantitatif dengan jenis penelitian deskriptif kuantitatif. Metode pengumpulan data dengan wawancara, pembagian kuesioner dan studi dokumentasi. Metode analisis yang di gunakan adalah regresi linier berganda. Hasil penelitian menunjukkan bahwa disiplin, konflik kerja dan stress kerja secara simultan dan parsial berpengaruh positif signifikan terhadap kinerja karyawan.
\end{abstract}

Kata Kunci: Disiplin; Konflik Kerja; Stress Kerja; Kinerja Karyawan

\section{PENDAHULUAN}

Kinerja karyawan sebagai kunci utama dalam pelaksanaan kegiatan perusahaan. Kinerja karyawan adalah hasil yang diterima oleh perusahaan dalam memperkerjakan karyawan di perusahaan. Kinerja karyawan menjadi hal yang sangat penting dalam mendukung perkembangan perusahaan. 
Tabel 1. Data Penjualan Perusahaan Tahun 2019

\begin{tabular}{ccccc}
\hline No & Bulan & $\begin{array}{c}\text { Target } \\
\text { Pendapatan } \\
\text { (Milyar) }\end{array}$ & $\begin{array}{c}\text { Jumlah Pendapatan } \\
\text { (Milyar) }\end{array}$ & Persentase \\
\hline 1 & Januari & $2,000,000,000$ & $1,865,256,000$ & $93.26 \%$ \\
2 & Februari & $2,000,000,000$ & $2,350,000,000$ & $117.50 \%$ \\
3 & Maret & $2,000,000,000$ & $1,713,424,000$ & $85.67 \%$ \\
4 & April & $2,000,000,000$ & $1,700,025,000$ & $85.00 \%$ \\
5 & Mei & $2,000,000,000$ & $1,698,424,000$ & $84.92 \%$ \\
6 & Juni & $2,000,000,000$ & $1,623,520,000$ & $81.18 \%$ \\
7 & Juli & $2,000,000,000$ & $1,603,424,000$ & $80.17 \%$ \\
8 & Agustus & $2,000,000,000$ & $1,601,324,000$ & $80.07 \%$ \\
9 & September & $2,000,000,000$ & $1,621,124,000$ & $81.06 \%$ \\
10 & Oktober & $2,000,000,000$ & $1,923,307,000$ & $96.17 \%$ \\
11 & November & $2,000,000,000$ & $1,924,120,000$ & $96.21 \%$ \\
12 & Desember & $2,000,000,000$ & $2,145,056,000$ & $107.25 \%$ \\
\hline
\end{tabular}

Sumber : PT SUN, 2019

Penurunan kinerja terlihat dari pengamatan data penjualan yang terjadi selama setahun tidak mampu mencapai target yang telah ditetapkan. Jumlah penjualan terendah terjadi di bulan Agustus dengan persentase $80.07 \%$ dari target dan penjualan tertinggi sebesar 117,50\% di bulan Februari. Hal ini memperlihatkan bahwa telah terjadi penurunan kinerja karyawan di perusahaan.

Disiplin sebagai salah satu hal yang diduga dapat menggangu kinerja karyawan. Disiplin kerja yang rendah membuat karyawan sering tidak bekerja dengan peraturan yang sudah ditetapkan oleh perusahaan. Disiplin dalam hal keterlambatan sering dilakukan oleh karyawan dalam menjalankan pekerjaan di perusahaan.

Tabel 2. Data Absensi Perusahaan Tahun 2019

\begin{tabular}{|c|c|c|c|c|c|}
\hline \multirow[b]{2}{*}{ Bulan } & \multirow[b]{2}{*}{$\begin{array}{c}\text { Jumlah } \\
\text { Karyawan }\end{array}$} & \multirow[b]{2}{*}{ HK } & \multirow[b]{2}{*}{$\begin{array}{c}\text { Target } \\
\text { Kehadiran }\end{array}$} & \multicolumn{2}{|c|}{ Keterlambatan } \\
\hline & & & & $\begin{array}{l}\text { Jumlah } \\
\text { (Orang) }\end{array}$ & $\begin{array}{c}\text { Orang } \\
(\%)\end{array}$ \\
\hline Januari & 63 & 26 & 1638 & 25 & $39.68 \%$ \\
\hline Februari & 63 & 23 & 1449 & 21 & $33.33 \%$ \\
\hline Maret & 63 & 25 & 1575 & 22 & $34.92 \%$ \\
\hline April & 63 & 23 & 1449 & 26 & $41.27 \%$ \\
\hline Mei & 63 & 25 & 1575 & 24 & $38.10 \%$ \\
\hline Juni & 63 & 18 & 1134 & 26 & $41.27 \%$ \\
\hline Juli & 63 & 27 & 1701 & 25 & $39.68 \%$ \\
\hline Agustus & 63 & 26 & 1638 & 23 & $36.51 \%$ \\
\hline September & 63 & 25 & 1575 & 16 & $25.40 \%$ \\
\hline Oktober & 63 & 27 & 1701 & 15 & $23.81 \%$ \\
\hline November & 63 & 25 & 1575 & 20 & $31.75 \%$ \\
\hline
\end{tabular}




\begin{tabular}{llllll}
\hline Desember & 63 & 24 & 1512 & 34 & $53.97 \%$ \\
Sumber : PT SUN, 2019 & & & & &
\end{tabular}

Karyawan PT Sukses Usaha Nirwana sering melakukan pelanggaran disiplin kerja berupa sakit dan absen bekerja tanpa alasan yang jelas. Dari pengamatan dilihat jumlah target kehadiran dengan keterlambatan. Jumlah keterlambatan tertinggi terjadi di Bulan Desember sebesar 53,97\% dikarenakan adanya libur tahun baru yang cukup panjang.

Selain disiplin, konflik juga dapat menjadi hal yang dapat menganggu kinerja karyawan. Akibat adanya konflik pada suatu perusahaan kinerja karyawan juga akan menjadi kurang produktif dan dapat menghambat kinerja. Dari pengamatan dapat dilihat jumlah konflik semakin meningkat dimana karyawan terlibat konflik sehingga pekerjaan tidak diurus dengan baik.

Tabel 3. Data Konflik Perusahaan Tahun 2019

\begin{tabular}{|c|c|c|c|}
\hline Bulan & $\begin{array}{l}\text { Jumlah } \\
\text { Konflik }\end{array}$ & Jabatan & $\begin{array}{c}\text { Permasalahan Konflik } \\
\text { Keseluruhan }\end{array}$ \\
\hline Januari & 1 & $\begin{array}{l}\text { Audit Staf } \\
\text { Cost Control }\end{array}$ & $\begin{array}{l}\text { Kesalahapahaman staf audit dalam } \\
\text { melakukan audit mengakibatkan } \\
\text { adanya kekurangan biaya }\end{array}$ \\
\hline Februari & - & - & - \\
\hline Maret & 3 & $\begin{array}{l}\text { Purchasing } \\
\text { Dengan Kasir }\end{array}$ & $\begin{array}{l}\text { Kesalahan bagian purchasing } \\
\text { dalam jumlah pembelian yang tidak } \\
\text { dikoordinasikan dengan bagian } \\
\text { kasir }\end{array}$ \\
\hline April & 2 & $\begin{array}{l}\text { Cost Control } \\
\text { dengan Stock } \\
\text { Clerk }\end{array}$ & $\begin{array}{ll}\text { Biaya yang mengalami kelebihan } \\
\text { karena adanya kesalahan } \\
\text { pemberian laporan dari bagian stok }\end{array}$ \\
\hline Mei & - & - & - \\
\hline Juni & - & - & - \\
\hline Juli & - & - & - \\
\hline Agustus & - & - & - \\
\hline September & 2 & $\begin{array}{l}\text { Kasir dengan } \\
\text { Membership }\end{array}$ & $\begin{array}{l}\text { Kasir yang kurang teliti dengan } \\
\text { tidak memasukkan } \\
\text { membership yang benar }\end{array}$ \\
\hline Oktober & - & - & - \\
\hline November & - & - & - \\
\hline Desember & 2 & $\begin{array}{l}\text { Account Payable } \\
\text { Audit Staff }\end{array}$ & $\begin{array}{l}\text { Bagian audit yang menemukan } \\
\text { adanya kesalahan pembuatan } \\
\text { laporan pada account payable }\end{array}$ \\
\hline
\end{tabular}

Sumber : PT SUN, 2019

Jumlah konflik paling banyak terjadi di Bulan Maret sebanyak 3 konflik. Konflik yang terjadi diantara satu divisi dengan divisi atau dengan divisi lain akan membuat kesulitan dikarenakan tidak ditemukannya penyelesaian permasalahan yang baik oleh karyawan. 
Tabel 4. Data Pengunduran Diri Perusahaan Tahun 2019

\begin{tabular}{|c|c|c|c|c|c|c|}
\hline Bulan & Jabatan & $\begin{array}{c}\text { Karyawan } \\
\text { Awal }\end{array}$ & $\begin{array}{l}\text { Jumlah } \\
\text { Masuk }\end{array}$ & $\begin{array}{c}\text { Jum } \\
\text { lah } \\
\text { Kelu } \\
\text { ar }\end{array}$ & $\begin{array}{c}\text { Karyaw } \\
\text { an } \\
\text { Akhir }\end{array}$ & Alasan \\
\hline Januari & HRD & 63 & - & 2 & 61 & 1. Target kerja yang \\
\hline Februari & Kasir & 63 & 5 & 3 & 63 & terlalu tinggi \\
\hline Maret & $\begin{array}{l}\text { Account } \\
\text { Payable }\end{array}$ & 63 & - & 3 & 60 & $\begin{array}{l}\text { 2. Sering mendapatkan } \\
\text { pekerjaan di luar job }\end{array}$ \\
\hline April & Bakery & 63 & 3 & - & 63 & desk \\
\hline Mei & $\begin{array}{l}\text { Credit } \\
\text { Card }\end{array}$ & 63 & - & 2 & 61 & $\begin{array}{l}\text { 3. Pimpinan kurang } \\
\text { mampu mengontrol }\end{array}$ \\
\hline Juni & - & 63 & - & - & 61 & emosi terhadap \\
\hline Juli & - & 63 & - & - & 61 & karyawan \\
\hline Agustus & $\begin{array}{l}\text { Audit } \\
\text { Staff }\end{array}$ & 63 & 5 & 3 & 63 & $\begin{array}{l}\text { 4. Tidak nyaman } \\
\text { dengan pemberian }\end{array}$ \\
\hline September & $\begin{array}{l}\text { Members } \\
\text { hip }\end{array}$ & 63 & 2 & 2 & 63 & $\begin{array}{l}\text { kompensasi } \\
\text { 5. Belum adanya }\end{array}$ \\
\hline Oktober & $\begin{array}{c}\text { Cost } \\
\text { Control }\end{array}$ & 63 & - & 3 & 60 & $\begin{array}{l}\text { kesempatan } \\
\text { pengembangan karir }\end{array}$ \\
\hline November & $\begin{array}{c}\text { Admin } \\
\text { Receiving }\end{array}$ & 63 & 1 & 1 & 63 & \\
\hline Desember & $\begin{array}{l}\text { Stock } \\
\text { Clerk }\end{array}$ & 63 & - & 2 & 62 & \\
\hline
\end{tabular}

Sumber : PT SUN, 2019

Dengan karyawan yang kurang mendapat motivasi dalam bekerja itu juga dapat menyebabkan stress kerja yang berdampak pada kinerja karyawan tersebut. Berdasarkan data dapat dilihat pada bulan Desember terjadi paling banyak pengunduran diri sebanyak 4 orang dikarenakan beberapa alasan seperti target kerja yang tinggi, sering mendapatkan pekerjaan tambahan, pimpinan yang bersikap kurang baik, kompensasi yang dinilai belum cukup, dan belum adanya kesempatan pengembangan karir.

\section{KAJIAN LITERATUR}

\subsection{Teori Pengaruh Disiplin terhadap Kinerja Karyawan}

Menurut Sinambela (2016 : 237), terdapat hubungan yang signifikan di antara variabel kinerja dengan disiplin kerja. Semakin tinggi disiplin kerja seseorang, maka akan semakin tinggi juga kinerja orang tersebut, disadari bahwa sangat banyak variabel yang berhubungan signifikan dengan kinerja pegawai, akan tetapi salah satu penyumbang utama kinerja adalah disiplin kerja. Dapat diberikan kesimpulan bahwa disiplin menjadi variabel yang memberikan dampak signifikan karena disiplin menjadi sebuah peraturan yang akan membentuk budaya kerja yang berdampak terhadap kinerja karyawan. 


\subsection{Teori Pengaruh Konflik Terhadap Kinerja Karyawan}

Menurut Triatna (2015:135), pada awalnya konflik organisasi akan mengakibatkan peningkatan kinerja organisasi. Namun pada titik tertentu konflik menjadi kondisi yang merugikan bagi organisasi karena konflik menjadi tidak terkendali. Dapat diberikan kesimpulan bahwa konflik dapat berdampak merugikan bagi organisasi jika konflik yang terjadi bersifat negatif. Konflik yang negatif akan menyebabkan perbedaaan pendapat diantara karyawan dan membuat kinerja karyawan menjadi terganggu.

\subsection{Teori Pengaruh Stres Kerja Terhadap Kinerja}

Menurut Hasibuan (2016:204), stres yang dialami karyawan akibat lingkungan yang dihadapinya akan memengaruhi kinerja dan kepuasan kerjanya. Prestasi kerja karyawan yang stres pada umumnya alan menurun karena mereka mengalami ketegangan pikiran dan berperilaku yang aneh, pemarah, dan suka menyendiri. Dapat diberikan kesimpulan bahwa stress kerja yang berlebihan akan menggangu pemikiran karyawan di dalam bekerja dan membuat karyawan tidak maksimal dalam menjalankan pekerjaan dan mempengaruhi kinerja.

Kerangka teoritis dalam penelitian ini akan menjelaskan hubungan antara masingmasing variabel yang dapat dilihat pada gambar dibawah ini :

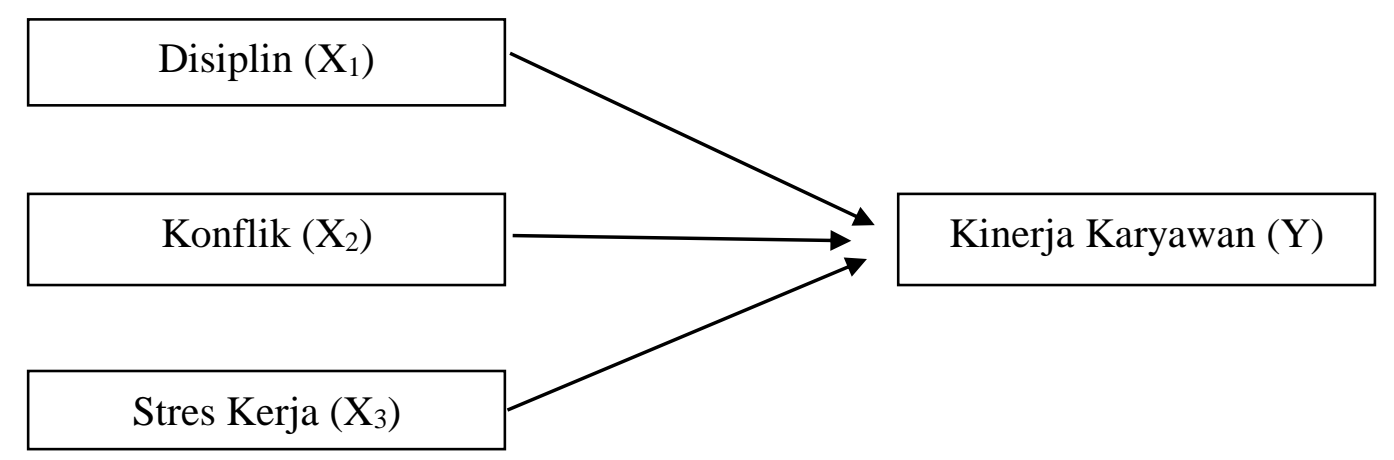

Gambar 1. Kerangka Teoritis

\section{METODOLOGI PENELITIAN}

\subsection{Tempat dan Waktu Penelitian}

Penelitian ini akan dilakukan di PT Sukses Usaha Nirwana (Nelayan Restoran) yang berlokasi di Center Point Mall di Jalan yang berlokasi di Jalan Jawa No.8. Waktu penelitian direncanakan dari bulan Januari - Desember 2019.

\subsection{Pendekatan, Jenis dan Sifat Penelitian}

Pendekatan penelitian ini berdasarkan pendekatan kuantitatif karena penelitian ini memiliki alur yang jelas dan teratur. Jenis penelitian ini merupakan jenis penelitian deskriptif kuantitatif. Sifat penelitian ini adalah deskriptif explanatory. 


\subsection{Populasi dan Sampel}

Populasi dalam penelitian ini adalah karyawan tetap di PT Sukses Usaha Nirwana dengan jumlah karyawan sebanyak 63 orang. Dalam pengambilan jumlah sampel akan menggunakan rumus sampling jenuh yaitu dengan menggunakan seluruh populasi, maka dalam penelitian ini sampel yang digunakan sebanyak 63. Sementara uji validitas dilakukan kepada 30 responden diambil dari cabang perusahaan yang berada di Kantor Restoran Nelayan Center Point Medan.

\subsection{Teknik Pengumpulan Data}

Teknik pengumpulan data yang digunakan adalah, wawancara (Interview), daftar pertanyaan (Questionare) dan Studi dokumentasi.

\subsection{Definisi Operasional Variabel Penelitian}

Berikut definisi operasional variabel yang akan digunakan yaitu :

Tabel 5. Definisi Operasional Variabel Penelitian

\begin{tabular}{|c|c|c|c|}
\hline Variabel & Definisi Operasional & Indikator & Pengukuran \\
\hline $\begin{array}{l}\text { Disiplin } \\
\quad\left(\mathrm{X}_{1}\right)\end{array}$ & $\begin{array}{l}\text { disiplin kerja adalah suatu } \\
\text { alat yang digunakan oleh } \\
\text { para manajer untuk } \\
\text { berkomunikasi } \\
\text { karyawan agar mereka } \\
\text { bersedia mengubah suatu } \\
\text { perilaku serta sebagai suatu } \\
\text { upaya untuk meningkatkan } \\
\text { kesadaran dan kesediaan } \\
\text { seseorang menaati semua } \\
\text { peraturan perusahaan dan } \\
\text { norma-norma sosial yang } \\
\text { berlaku. } \\
\text { Menurut Rivai dan Sagala } \\
\text { (2013: 825) }\end{array}$ & $\begin{array}{l}\text { 1. Tujuan dan } \\
\text { kemampuan } \\
\text { 2. Balas jasa } \\
\text { 3. Sanksi hukuman } \\
\text { Menurut Hasibuan } \\
(2016: 194)\end{array}$ & Skala Likert \\
\hline $\begin{array}{c}\text { Konflik } \\
\left(\mathrm{X}_{2}\right)\end{array}$ & $\begin{array}{l}\text { Konflik merupakan suatu } \\
\text { proses yang dimulai bila } \\
\text { salah satu pihak merasakan } \\
\text { bahwa pihak lain telah } \\
\text { mempengaruhi } \\
\text { negatif, atau akan secara } \\
\text { mempengaruhi } \\
\text { negatif, sesuatu yang menjadi } \\
\text { perhatian pihak pertama. } \\
\text { Menurut }\end{array}$ & $\begin{array}{l}\text { 1. Konflik yang dapat } \\
\text { diamati dan konflik } \\
\text { yang dapat } \\
\text { dirasakan } \\
\text { 2. Konflik terlihat } \\
\text { secara terbuka } \\
\text { 3. Penyelesaian atau } \\
\text { tekanan terhadap } \\
\text { konflik } \\
\text { Menurut Wijono (2010 }\end{array}$ & Skala Likert \\
\hline
\end{tabular}




\begin{tabular}{|c|c|c|c|}
\hline & $(2010: 161)$ & : 232-233) & \\
\hline $\begin{array}{c}\text { Stres } \\
\text { Kerja } \\
\left(\mathrm{X}_{3}\right)\end{array}$ & $\begin{array}{l}\text { Stres kerja adalah perasaan } \\
\text { tertekan yang dialami } \\
\text { karyawan dalam menghadapi } \\
\text { pekerjaan. } \\
\text { Menurut Mangkunegara } \\
(2013: 157)\end{array}$ & $\begin{array}{l}\text { 1. Tingkat absensi } \\
\text { karyawan } \\
\text { 2. Fluktuasi staf yang } \\
\text { tinggi } \\
\text { 3. Produktivitas } \\
\text { rendah }\end{array}$ & Skala Likert \\
\hline $\begin{array}{c}\text { Kinerja } \\
\text { Karyawan } \\
\text { (Y) }\end{array}$ & $\begin{array}{l}\text { Kinerja adalah kuantitas atau } \\
\text { kualitas hasil kerja individu } \\
\text { atau sekelompok di dalam } \\
\text { organisasi dalam } \\
\text { melaksanakan tugas pokok } \\
\text { dan fungsi yang berpedoman } \\
\text { pada norma, standar } \\
\text { operasional prosedur, kriteria } \\
\text { dan ukuran yang telah } \\
\text { ditetapkan atau yang berlaku } \\
\text { dalam organisasi. } \\
\text { Menurut Torang (2013:74) }\end{array}$ & $\begin{array}{l}\text { Menurut Hamali } \\
(2016: 246) \\
\text { 1. Kualitas } \\
\text { 2. Efektif } \\
\text { 3. Produktivitas } \\
\text { Menurut Moeheriono } \\
(2014: 113)\end{array}$ & Skala Likert \\
\hline
\end{tabular}

\subsection{Model Analisis Data Penelitian}

Menurut Sujarweni (2014:149), "regresi linear berganda merupakan regeresi yang memiliki satu variabel dependen dan lebih dari satu variabel independen." Dapat dihitung dengan bantuan perangkat lunak Statistical Product and Service Solution (SPSS) dengan rumus:

$Y=a+b_{1} X_{1}+b_{2} X_{2}+b_{3} X_{3}+e$

Keterangan:

Y = Kinerka Karyawan

a $\quad=$ Konstanta

$\mathrm{b}_{1-3}=$ Koefisien regresi variabel independen

$\mathrm{X}_{1} \quad=$ Disiplin

$\mathrm{X}_{2} \quad=$ Konflik

$\mathrm{X}_{3}=$ Stres Kerja

e $\quad=$ Standard Error 


\section{HASIL DAN PEMBAHASAN}

\subsection{Uji Asumsi Klasik}

\section{Uji Normalitas}

\subsection{Uji Statistik}

Pada uji statistic akan menggunakan uji one sample kolgomorov smirnov.

Tabel 6. Uji Normalitas One Sample Kolmogorov Smirnov

\begin{tabular}{|c|c|c|}
\hline \multicolumn{3}{|c|}{ One-Sample Kolmogorov-Smirnov Test } \\
\hline & & $\begin{array}{c}\text { Unstandardiz } \\
\text { ed Residual }\end{array}$ \\
\hline \multicolumn{2}{|l|}{$\mathrm{N}$} & 63 \\
\hline \multirow[t]{2}{*}{ Normal Parameters ${ }^{\mathrm{a}, \mathrm{b}}$} & Mean & .0000000 \\
\hline & $\begin{array}{l}\text { Std. } \\
\text { Deviation }\end{array}$ & 2.28546393 \\
\hline Most Extreme & Absolute & .053 \\
\hline \multirow[t]{2}{*}{ Differences } & Positive & .053 \\
\hline & Negative & -.047 \\
\hline \multicolumn{2}{|l|}{ Test Statistic } & .053 \\
\hline \multicolumn{2}{|l|}{ Asymp. Sig. (2-tailed) } & $.200^{\mathrm{c}, \mathrm{d}}$ \\
\hline \multicolumn{3}{|c|}{ a. Test distribution is Normal. } \\
\hline \multicolumn{3}{|l|}{ b. Calculated from data. } \\
\hline \multicolumn{3}{|c|}{ c. Lilliefors Significance Correction. } \\
\hline \multicolumn{3}{|c|}{$\mathrm{d}$. This is a lower bound of the true significance. } \\
\hline
\end{tabular}

Sumber : Hasil Penelitian, 2020 (Data diolah)

Hasil uji normalitas Kolmogorov Smirnov menunjukkan nilai signifikan 0,200 > 0,05 dengan demikian dari hasil uji Kolmogorov Smirnovmenunjukkan data terdistribusi normal.

\section{Uji Multikolinearitas}

\begin{tabular}{llll}
\multicolumn{4}{c}{ Tabel 7. Multikolinearitas } \\
\hline \multicolumn{4}{c}{$\begin{array}{c}\text { Coefficients } \\
\text { Collinearity } \\
\text { Model }\end{array}$} \\
\cline { 3 - 4 } & & Tolerance & VIF \\
\hline 1 & (Constant) & & \\
& Disiplin & .684 & 1.462 \\
& Konflik & .612 & 1.635 \\
& Stres & .862 & 1.160
\end{tabular}

a. Dependent Variable: Kinerja

Sumber : Hasil Penelitian, 2020 (Data diolah)

Nilai tolerance untuk variabeldisiplin, konflik, stres berada diatas 0,10 sedangkan nilai VIF variabel disiplin, konflik dan stres berada dibawah 10. Dengan demikian pada uji multikolinearitas tidak terjadi korelasi antar variabel independen. 


\section{Uji Heteroskedasitas}

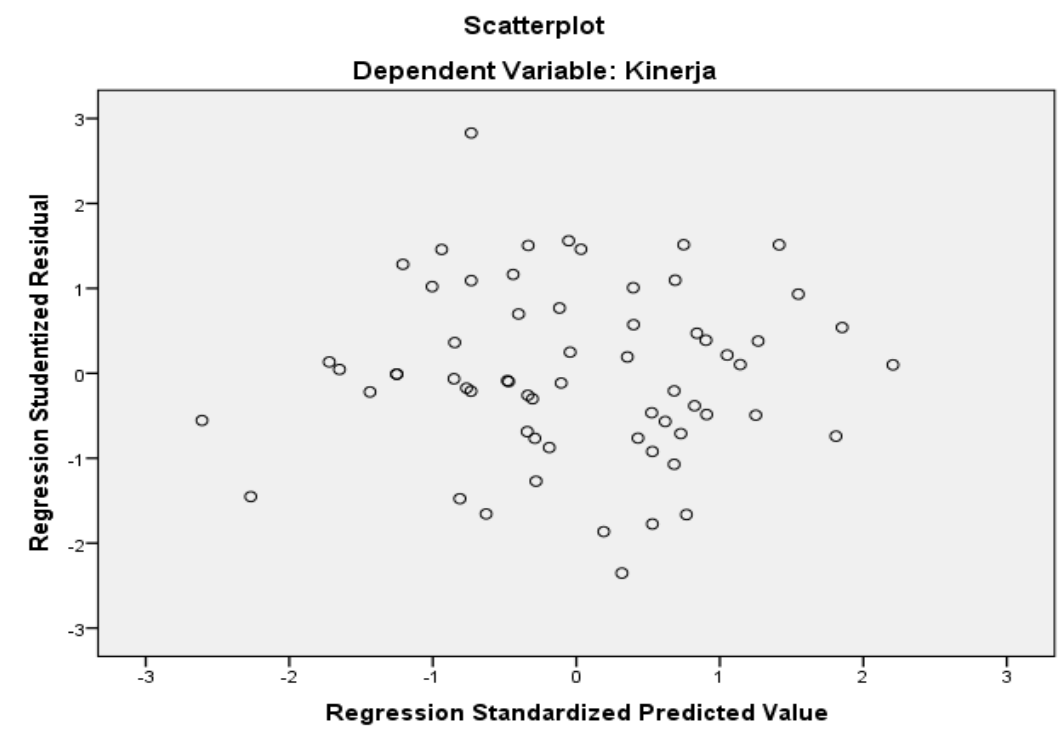

Sumber : Hasil Penelitian, 2020 (Data diolah)

Gambar 2. Uji Heteroskedastisitas Grafik Scatterplot

Dari grafik scatterplot terlihat bahwa titik-titik menyebar dengan pola yang tidak jelas baik diatas maupun dibawah angka nol (0) pada sumbu Y, tidak berkumpul disatu tempat, sehingga dari grafik scatterplotdapat disimpulkan bahwa tidak terjadi heteroskedastisitas pada model regresi.

\section{Uji Glejser}

Tabel 8. Uji Glejser

\begin{tabular}{|c|c|c|c|c|c|c|}
\hline \multicolumn{7}{|c|}{ Coefficients $^{\mathbf{a}}$} \\
\hline \multirow{2}{*}{\multicolumn{2}{|c|}{ Model }} & \multicolumn{2}{|c|}{$\begin{array}{l}\text { Unstandardized } \\
\text { Coefficients }\end{array}$} & \multirow{2}{*}{$\begin{array}{c}\text { Standardized } \\
\text { Coefficients } \\
\text { Beta }\end{array}$} & \multirow[b]{2}{*}{$\mathrm{t}$} & \multirow[b]{2}{*}{ Sig. } \\
\hline & & B & Std. Error & & & \\
\hline \multirow[t]{4}{*}{1} & (Constant) & 1.815 & 1.278 & & 1.421 & .161 \\
\hline & Disiplin & -.012 & .056 & -.035 & -.223 & .824 \\
\hline & Konflik & .043 & .062 & .117 & .705 & .484 \\
\hline & Stres & -.036 & .049 & -.103 & -.738 & .464 \\
\hline
\end{tabular}

a. Dependent Variable: abust

Sumber : Hasil Penelitian, 2020 (Data diolah)

Hasil Uji Gletjer Pada Tabel IV.12 diatas menunjukkan nilai signifikan dari disiplin $0,824>0,05$, konflik 0,484>0,05, stres 0,464 > 0,05 dengan demikian dari hasil uji Glejser dapat dikatakan tidak terjadi masalah heteroskedastisitas.

\subsection{Hasil Analisis Data Peneltian}

Pada hasil dari penelitian menggunakan model penelitian analisis regresi linier berganda. 
Tabel 9. Analisis Linier Berganda

\begin{tabular}{|c|c|c|c|c|c|c|}
\hline \multicolumn{7}{|c|}{ Coefficients $^{\mathrm{a}}$} \\
\hline \multirow[b]{2}{*}{ Model } & & \multicolumn{2}{|c|}{$\begin{array}{l}\text { Unstandardized } \\
\text { Coefficients }\end{array}$} & $\begin{array}{l}\text { Standardized } \\
\text { Coefficients }\end{array}$ & \multirow[b]{2}{*}{$t$} & \multirow[b]{2}{*}{ Sig. } \\
\hline & & B & Std. Error & Beta & & \\
\hline 1 & (Constant) & 1.288 & 2.065 & & .624 & .535 \\
\hline & Disiplin & .200 & .090 & .219 & 2.214 & .031 \\
\hline & Konflik & .414 & .100 & .436 & 4.161 & .000 \\
\hline & Stres & .312 & .080 & .344 & 3.901 & .000 \\
\hline
\end{tabular}

a. Dependent Variable: Kinerja

Sumber : Hasil Penelitian, 2020 (Data diolah)

Kinerja karyawan $=1.288+0.200$ Disiplin+0.414Konflik + 0,312Stres Kerja

Pemahaman dari regresi linier berganda diatas adalah:

1. Konstanta sebesar 1.288 menyatakan bahwa jika disiplin, konflik dan stress tidak ada atau konstan maka kinerja karyawan sebesar 1.288 satuan.

2. Koefisien regresi disiplin sebesar 0.200 dan bernilai positif, hal ini menyatakan bahwa setiap kenaikan disiplin 1 satuan akan meningkatkan kinerja sebesar 0.200 satuan dengan anggapan variabel lainnya tetap.

3. Koefisien regresi konflik sebesar 0.414 dan bernilai positif, hal ini menyatakan bahwa setiap kenaikan konflik 1 satuan akan akan meningkatkan kinerja sebesar 0.414 satuan dengan anggapan variabel lainnya tetap.

4. Koefisien regresi stress kerja sebesar 0.312 dan bernilai positif, hal ini menyatakan bahwa setiap kenaikan stress kerja 1 satuan akan akan meningkatkan kinerja sebesar 0.312 satuan dengan anggapan variabel lainnya tetap.

\subsection{Koefisien Determinasi Hipotesis $\left(\mathbf{R}^{2}\right)$}

Tabel 10. Uji Koefisien Determinasi

\begin{tabular}{llrrr}
\hline & & \multicolumn{2}{c}{ Model Summary $^{\mathbf{b}}$} \\
Model & R & R Square & $\begin{array}{c}\text { Adjusted R } \\
\text { Square }\end{array}$ & $\begin{array}{l}\text { Std. Error of } \\
\text { the Estimate }\end{array}$ \\
\hline 1 & $.777^{\text {a }}$ & .604 & .584 & 2.34285
\end{tabular}

a. Predictors: (Constant), Stres, Disiplin, Konflik

b. Dependent Variable: Kinerja

Sumber : Hasil Penelitian, 2020 (Data diolah)

Hasil Uji Koefisien Determinasi diperoleh nilai Adjusted $R$ square sebesar 0.584 hal ini berarti $58,4 \%$ dari variasi variabel dependen yaitukinerja karyawan yang dapat dijelaskan oleh variasi variabel independen disiplin, konflik dan stressisanya sebesar 41,6\% (100\% $58,4 \%$ ) dijelaskan oleh variabel lain yang tidak diteliti pada penelitian ini, seperti budaya organisasi, kompensasi dan lingkungan kerja. 


\subsection{Pengujian Hipotesis Secara Simultan (Uji F)}

Tabel 11. Uji Simultan (Uji F)

ANOVA ${ }^{\mathrm{a}}$

\begin{tabular}{|rl|r|r|r|r|r|}
\hline \multicolumn{2}{|l|}{ Model } & \multicolumn{1}{|c|}{$\begin{array}{c}\text { Sum of } \\
\text { Squares }\end{array}$} & df & \multicolumn{1}{c|}{$\begin{array}{c}\text { Mean } \\
\text { Square }\end{array}$} & F & \multicolumn{1}{c|}{ Sig. } \\
\hline 1 & Regression & 493.708 & 3 & 164.569 & 29.982 & $.000^{\mathrm{b}}$ \\
& Residual & 323.847 & 59 & 5.489 & & \\
& Total & 817.556 & 62 & & & \\
\hline
\end{tabular}

a. Dependent Variable: Kinerja

b. Predictors: (Constant), Stres, Disiplin, Konflik

Sumber : Hasil Penelitian, 2020 (Data diolah)

Nilai $\mathrm{f}_{\text {tabel }}$ diperoleh dari :

df $1=\mathrm{k}-1=4-1=3$, di mana $\mathrm{k}$ adalah $:$ jumlah variabel dependen dan independen

df $2=\mathrm{n}-\mathrm{k}=63-4=59$, di mana $\mathrm{n}$ adalah : jumlah sampel dapat dilihat dari baris ke 58, kolom ke 2. $\mathrm{f}_{\text {tabel }}$ sesuai dengan tabel $\mathrm{F}$ adalah 3,15. Dari tabel di atas dapat terlihat bahwa nilai $\mathrm{F}_{\text {hitung }}$ sebesar 29,982 dengan probabilitas 0,000, karena probabilitasnya lebih kecil dari 0,05, maka model regresi dapat digunakan untuk memprediksi keputusan pembelian. Hal ini juga dapat dilihat dari $\mathrm{F}_{\text {hitung }}(29,982)>\mathrm{F}_{\text {tabel }}(3,15)$, maka $\mathrm{H}_{4}$ diterima yang berarti bahwa variabel disiplin, konflik dan stres simultanberpengaruh terhadap kinerja karyawan.

\subsection{Pengujian Hipotesis Secara Parsial (Uji t)}

Tabel 13. Uji Parsial (Uji t)

\section{Coefficients $^{\mathrm{a}}$}

\begin{tabular}{rlrrrrr} 
& \multicolumn{2}{c}{$\begin{array}{l}\text { Unstandardized } \\
\text { Coefficients }\end{array}$} & \multicolumn{2}{c}{$\begin{array}{c}\text { Standardized } \\
\text { Coefficients }\end{array}$} \\
\multicolumn{1}{l}{ Model } & & \multicolumn{1}{c}{ B } & Std. Error & \multicolumn{1}{c}{ Beta } & \multicolumn{1}{c}{ t } & \multicolumn{1}{c}{ Sig. } \\
\hline 1 & (Constant) & 1.288 & 2.065 & & .624 & .535 \\
& Disiplin & .200 & .090 & .219 & 2.214 & .031 \\
& Konflik & .414 & .100 & .436 & 4.161 & .000 \\
& Stres & .312 & .080 & .344 & 3.901 & .000
\end{tabular}

a. Dependent Variable: Kinerja

Sumber : Hasil Penelitian, 2020 (Data diolah)

Nilai $\mathrm{t}$ ditentukan signifikan $5 \%$ dan derajat bebas : $\mathrm{df}=\mathrm{n}-\mathrm{k}(\mathrm{df}=$ jumlah sampel dan $\mathrm{k}=$ jumlah variabel keseluruhan) yaitu $\mathrm{df}=63-4=59$. Uji thitung yang dilakukan adalah : uji dua arah maka ttabel yang digunakan adalah t 5\% atau t0,05 (62) $=2.00100$.

1. Dari hasil uji $\mathrm{t}$ di atas dapat disimpulkan bahwa untuk variabel komunikasi, diperoleh $t_{\text {hitung }}(2.214)>t_{\text {tabel }}(2,000)$ serta nilai probabilitas $(0,000)<0,05$, maka $\mathrm{H}_{1}$ diterima berarti ada pengaruh signifikan positif dari variabel disiplin secara parsial terhadap kinerja karyawan. 
2. Untuk variabel promosi, diperoleh $t_{\text {hitung }}(4.161)>t_{\text {tabel }}(2,000)$ serta nilai probabilitas $(0,000)<0,05$, maka $\mathrm{H}_{2}$ diterima berarti ada pengaruh signifikan positif dari variabel konflik secara parsial terhadap kinerja karyawan.

3. Untuk variabel stres, diperoleh $t_{\text {hitung }}(3.901)>t_{\text {tabel }}(2,000)$ serta nilai probabilitas $(0,000)<0,05$, maka $\mathrm{H}_{3}$ diterima berarti ada pengaruh signifikan positif dari variabel stressecara parsial terhadap kinerja karyawan.

\subsection{Pembahasan Hasil Penelitian}

\section{A. Pengaruh Disiplin Terhadap Kinerja Karyawan}

Hasil penelitian yang dilakukan peneliti membuktikan bahwa adanya pengaruh disiplin terhadap kinerja karyawan pada PT Sukses Usaha Nirwana. Sejalan dengan hipotesis pertama $\left(\mathrm{H}_{1}\right)$. Hal ini dapat dilihat dari hasil uji parsial (Uji-t) dimana nilai $t_{\text {hitung }}>t_{\text {tabel }}$ $(2.214>2,000)$ dan nilai signifikansi $0,000<0,05$.

Hasil penelitian ini sejalan dengan teori Sinambela (2016:237), terdapat hubungan yang signifikan di antara variabel kinerja dengan disiplin kerja. Semakin tinggi disiplin kerja seseorang, maka akan semakin tinggi juga kinerja orang tersebut, disadari bahwa sangat banyak variabel yang berhubungan signifikan dengan kinerja pegawai, akan tetapi salah satu penyumbang utama kinerja adalah disiplin kerja.

Hasil penelitian ini juga sesuai dengan penelitian terdahulu oleh Putri (2018) dengan judul Pengaruh Lingkungan Kerja Fisik, Stres Kerja dan Disiplin Kerja Terhadap Kinerja Karyawan Bagian Produksi PT Kimia Farma Tbk Semarang. Hasil penelitian menunjukkan bahwa variabel disiplin berpengaruh secara positif dan signifikan terhadap kinerja karyawan.

Hasil dari kuesioner juga menunjukkan jawaban dominan pada jawaban kurang setuju (nilai 2). Hal ini menunjukkan bahwa disiplin yang dimiliki oleh karyawan pada saat ini belum baik. Jawaban dominan juga dijawab sebesar 19,5\% menyatakan kurang setuju dalam variabel disiplin yang memperlihatkan bahwa karyawan dominan belum mampu menjalankan disiplin dengan baik.

\section{B. Pengaruh Konflik Terhadap Kinerja Karyawan}

Hasil penelitian yang dilakukan peneliti membuktikan bahwa adanya pengaruh konflik terhadap kinerja karyawan pada PT Sukses Usaha Nirwana. Sejalan dengan hipotesis kedua $\left(\mathrm{H}_{2}\right)$. Hal ini dapat dilihat dari hasil uji parsial (Uji-t) dimana nilai $t_{\text {hitung }}>\mathrm{t}_{\text {tabel }}(4.161>2,000)$ dan nilai signifikansi $0,000<0,05$. Konflik merupakan warisan kehidupan sosial yang boleh berlaku dalam berbagai keadaan akibat daripada berbangkitnya keadaan ketidaksetujuan, kontroversi, dan pertentangan diantara dua pihak atau lebih secara berkesinambungan. Konflik yang baik akan meningkatkan kinerja karyawan pada PT Sukses Usaha Nirwana. Akibat yang dirasakan karyawan PT Sukses Usaha Nirwana dengan adanya konflik dalam organisasi yang positif dapat meningkatkan ritme kerja, membuat pekerjaan cepat selesai dan meningkatkan kedisiplinan karyawan.

Hasil penelitian ini sejalan dengan teori Triatna (2015:135), pada awalnya konflik organisasi akan mengakibatkan peningkatan kinerja organisasi. Hasil penelitian ini juga sesuai dengan penelitian terdahulu oleh Giovani (2013) dengan judul Pengaruh Konflik Peran, Konflik kerja dan Stres Kerja Terhadap Kinerja Karyawan Pada PT Air Manado. Hasil 
penelitian menunjukkan bahwa variabel konflik berpengaruh secara positif dan signifikan terhadap kinerja karyawan.

\section{Pengaruh Stres Terhadap Kinerja Karyawan}

Hasil penelitian yang dilakukan peneliti membuktikan bahwa adanya pengaruh stres terhadap kinerja karyawan pada PT Sukses Usaha Nirwana. Sejalan dengan hipotesis ketiga $\left(\mathrm{H}_{3}\right)$. Hal ini dapat dilihat dari hasil uji parsial (Uji-t) dimana nilai $t_{\text {hitung }}>\mathrm{t}_{\text {tabel }}(3.901>2,001)$ dan nilai signifikansi $0,000<0,05$. Hal ini berarti bahwa karyawan PT Sukses Usaha Nirwana memiliki stres pada tingkat rendah sampai pada tingkat moderat bersifat fungsional dalam arti berperan sebagai pendorong peningkatan kinerja pegawai. Ketika seorang karyawan maupun manajer mampu mengelola stresnya dengan baik, maka konsekuensinya adalah fungsional (positif).

Hasil penelitian ini sejalan dengan teoriHasibuan (2016:204), stres yang dialami karyawan akibat lingkungan yang dihadapinya akan memengaruhi kinerja dan kepuasan kerjanya. Prestasi kerja karyawan yang stres pada umumnya alanmenurun karena mereka mengalami ketegangan pikiran dan berperilaku yang aneh, pemarah, dan suka menyendiri.

\section{SIMPULAN DAN REKOMENDASI}

Berdasarkan hasil dan pembahasan penelitian, maka penulis membuat beberapa kesimpulan. Hasil pengujian hipotesis secara parsial bahwa disiplin berpengaruh positif dan signifikan. Variabel konflik secara parsial berpengaruh positif dan signifikan. Variabel stress kerja secara parsial berpengaruh positif dan signifikan. Hasil uji koefisien determinasi menunjukkan 58,4\% dari variasi variabel dependen kinerja karyawan yang dapat dijelaskan oleh variabel independen disiplin, konflik, stress kerja sisanya 41,6\% divariasikan oleh variabel lain yang tidak diteliti pada penelitian ini.

\section{DAFTAR PUSTAKA}

Hamali, Ali Yusuf. 2016. Pemahaman Manajemen Sumber Daya Manusia. CAPS (Canter for Academic Publishing Service). Yogyakarta.

Hasibuan, H.M.S.P. 2016. Manajemen Sumber Daya Manusia, Edisi Revisi, Jakarta :Bumi Aksara. Moeheriono. 2016. Pengukuran Kinerja Berbasis Kompetensi. Edisi Revisi. Jakarta: PT. RajaGrafindo Persada.

Sinambela, Lijan Poltak. 2016. Manajemen Sumber Daya Manusia Membangun Tim Kerja yang Solid Untuk Meningkatkan Kinerja. Jakarta : Bumi Aksara.

Sujarweni, V. Wiratna. 2014. Metodologi Penelitian. Yogyakarta: Pustaka Baru Press.

Triatna, Cepi. 2015. Perilaku dalam Organisasi. Bandung: PT. Remaja Rosdakarya.

Wijono, Sutarto. 2010. Psikologi Industri dan Organisasi. Jakarta: Fajar. Interpratama Offset. 